\title{
EUROPEAN TRAVEL AND TOURISM ICT READINESS: PCA/SWARA APPROACH
}

\author{
Žarko Rađenović ${ }^{1}$ (D) \\ Ivana Marjanović ${ }^{2}$ (i)
}

DOI: https://doi.org/10.31410/tmt.2020.131

\begin{abstract}
The development of information and communication technology has led to the transformation of traditional business practices in all sectors of the economy. Information and communication technologies in the field of tourism represent a generator of change and drivers of development, by enabling the creation and retention of a large number of jobs, business opportunities and significant added value. Given the well-recognized value of the information and communication technologies in tourism, this chapter sought to identify the countries with the highest level of travel and tourism ICT readiness. Therefore, a two-step analysis was applied where in the first step the weights were determined using two approaches, PCA and SWARA. In the second step, using multicriteria analysis, the evaluation of ICT readiness of European countries was performed. The results indicate that the application of weight coefficients determined by different approaches in the same multicriteria method leads to moderate rank inversion.
\end{abstract}

Keywords: Tourism economics, PCA/SWARA approach, Tourism ICT readiness, Tourism business efficiency using ICT.

\section{INTRODUCTION}

$I^{t}$ is evident that in modern conditions, information and communication technologies (ICTs) are an important factor in strengthening the competitiveness of tourism organizations, destinations and in shaping the market itself (Berne et al., 2012; Navío-Marco et al., 2018; Kontogianni \& Alepis, 2020). One of the first sectors to successfully utilize and integrate ICTs into business processes was the tourism sector (Reinders \& Baker, 1998), to adequately tailor supply to consumer needs (Bramwell \& Lane, 1999). Thanks to digitalization, there have been significant changes in the industry, which are primarily reflected in the transformation of the industry structure by changing barriers to entry, reorganization of the channels of distribution, an increase of transparency, improvements of business efficiency and costs optimization (Assaf \& Tsionas, 2018). The application of ICTs in tourism has led to the creation of new pathways for relationships through tourism distribution channels, increased competitiveness and efficiency in the sector, and improved business performance, and ICTs have become an indispensable element of business development (Berné et al., 2015). The reorganization of distribution channels implies that ICTs have enabled the development of new ways of cooperation among members of different channels of distribution (Law et al., 2011). The usefulness of ICTs in this area is primarily due to three main factors (Wang \& Fesenmaier, 2007): the interdependency of an extensive assortment of services and goods, the large number of small individual operators, and the spatial separation between individuals' holiday destinations and their place of residence. The significance of ICTs for the tourism sector was recognized by the World Economic Forum by defining ICT readiness as one of the pillars in the Travel and Tourism Competitiveness Index (TTCI).

\footnotetext{
$1 \quad$ University of Niš, Innovation Center, Vojvode Tankosića 14/8, Niš, Serbia

2 University of Niš, Faculty of Ecnomics, Trg kralja Aleksandra Ujedinitelja 11, Niš, Serbia
} 
Bearing in mind the great importance of ICTs for the tourism industry, this paper aims to indicate and evaluate the acceptance of ICTs in the tourism sector of European countries by applying statistical and multicriteria methods. In addition, the sub-goal is to point out the importance of adequately determining the importance of indicators based on which the evaluation of ICT readiness in the tourism sector is performed.

The paper is structured as follows: after the introduction, the second part of the paper points out the contribution of the tourism sector to the economy and the importance of ICTs for the tourism sector. The third part provides an overview of the methodology based on which it is possible to evaluate ICTs readiness in the travel and tourism sector, while the fourth part is dedicated to the analysis of results and discussion. The concluding remarks are offered in the fifth part.

\section{IMPORTANCE OF ICT FOR THE TOURISM SECTOR}

The tourism sector, as one of the world's largest sectors, is a very important component of the economic and social activities of many countries, as it contributes to the creation of new jobs and business opportunities (Brandt et al., 2017). This sector is accounted for 10.3\% of global GDP and 330 million jobs, or $10.4 \%$ of total employment in 2019 (WTTC, 2019). Tourism represents an important economic sector for all countries, developed and underdeveloped. Tourism contributes directly, on average, $4.4 \%$ of GDP, $6.9 \%$ of employment and $21.5 \%$ of service exports in OECD countries (OECD, 2020). In recent decades, the tourism sector has been defined as an information-intensive and IT-based industry, where most tour operators use ICTs to distribute their products, improve communication and create alternative distribution channels (Karanasios \& Burgess, 2008). The speed and efficiency of ICTs infrastructure is a prerequisite for the development of tourism in modern conditions. The application of ICTs enables the integration of supply chain management and customer relations, thus facilitating operations and improving employee efficiency. The transformational effect of ICTs on the tourism industry has been particularly pronounced in recent decades and affects both sides of the tourism market, the demand and the supply side. On the demand side, there is a request for personalized tourist experiences. Through new technologies, users of tourist services have the opportunity to share information about the quality of service, destination, and other issues of their interest. The application of ICTs enables consumers to search, customize and exploit tourism products while supporting the globalization of the tourism industry by providing tools for the development, management and distribution of offerings around the world (Bethapudi, 2013). The usage of ICTs in the tourism sector leads to the emergence of new and transformation of conventional tourism experiences (Neuhofer et al., 2014). It is evident that in modern conditions, business competitiveness, among other things, implies the presence of companies in the virtual market. Insufficient adoption of ICTs prevents companies from reaping the benefits of e-services which could lead to gradual crowding out by global competition.

Sophistication and integration of ICTs in all spheres of life cause changes in market conditions, which is especially noticeable in the tourism sector, where there has been a significant increase in transparency in the offer of destinations while reducing the asymmetry of information between suppliers and consumers (Bradić-Martinović \& Miletić, 2017). The development possibilities of ICTs in tourism are displayed in the globalization of the tourism industry and the transformation of the market from local to global. The impact of ICTs is primarily reflected in four different aspects (Aramendia Muneta \& Ollo López, 2013): developing new business opportunities, improving productivity and efficiency, gaining a competitive advantage, and enabling new ways of managing tour operators. ICTs facilitates the business of tour operators by 
enabling direct contact with clients and partners, increases management efficiency, facilitates market research, provides adequate ability to respond and manage crises, enables product differentiation and personalization, enables monitoring and evaluation of business performance. Among the main benefits of using ICT for tourism enterprises are (Januszevska et al., 2015): creating new business relationships among members of distribution channels to facilitate cooperation and increase efficiency; easy access to data and information; enabling joint value creation; gaining a competitive advantage; enabling the promotion and distribution of tourism products directly to consumers, reducing dependence on intermediaries; enabling sales analysis; speeding up management procedures and improving efficiency; enabling better use of resources available to the tourist company.

An increasing body of literature analyzes the impact of ICTs on the tourism industry (Bethapudi, 2013; Mihajlović, 2012; Law et al., 2014; Zeng \& Gerritsen, 2014; Kladou \& Mavragani, 2015; Narangajavana et al., 2017; Štetić et al., 2017; Mandić \& Praničević, 2019; Patwary et al., 2020; Damnjanović, 2016; Petrovic \& Milićević, 2020; Kumar \& Kumar, 2020). An extensive overview of consumers' acceptance of e-tourism is given in Ukpabi and Karjaluoto (2017). However, the application of ICTs in the tourism sector faces certain difficulties. The diversity of the tourism sector, which is reflected in the fragmentation of the market, a large volume of personalized transactions and products, a large volume of structured and standardized data, as well as different types of customers places high demands on information systems (Werthner \& Klein, 1999). Duffy (2010) identified the main factors that facilitate the application of ICTs in the tourism sector, but also the main obstacles. Factors that encourage the application of ICTs include the simplicity and usefulness of ICTs, management support, the possibility of user involvement, the availability of internal and external expertise. The main obstacles are security concerns, lack of training, lack of capital, maintenance of hardware and software, and fear of technology.

Nevertheless, the benefits and advantages that the application of ICTs in the tourism sector provides far outweigh the potential disadvantages and difficulties in the application of ICTs. Therefore, the aspiration of most developed and developing countries is to integrate ICTs into the tourism sector as much as possible, with different countries having different success rates. With this in mind, this paper seeks to evaluate the level of ICT readiness of European countries in the tourism sector by applying the methods of multicriteria analysis.

\section{DATA AND METHODOLOGY}

This research will analyze the information technology readiness of the tourism sector of selected European countries based on the values of ICT indicators for tourism formed by the World Economic Forum. ${ }^{3}$ These indicators are an integral part of the TTCI, which serves to rank countries according to the degree of mutual competitiveness in the tourism sector. Table 1 presents descriptive statistics for the values of ICT indicators for selected European countries, from the Total Competitiveness Report for the year 2019 year (WEF, 2019). Selected ICT sub-indicators are:

- ICT use for business to business transactions (C1) - What extent do businesses, in a particular country, use ICTs for transactions with other businesses? - 1 to 7 score, where $1=$ not at all, $7=$ to a great extent,

Selected European countries: Albania, Austria, Belgium, Bosnia and Herzegovina, Bulgaria, Croatia, Cyprus, Czech Republic, Denmark, Estonia, Finland, France, Germany, Greece, Hungary, Ireland, Italy, Luxembourg, Malta, Moldova, Montenegro, Netherlands, North Macedonia, Norway, Poland, Portugal, Romania, Russian Federation, Serbia, Slovak Republic, Slovenia, Spain, Sweden, Switzerland, Turkey, Ukraine and United Kingdom. 
- ICT use for business to customer transactions (C2) - What extent do businesses, in a particular country, use the Internet for selling their goods and services to consumers? 1 to 7 score, where $1=$ not at all, $7=$ to a great extent,

- Percentage of the adult population of Internet users (C3) - Percentage of individuals who used the internet from any location and for any purpose, irrespective of the device and network used, in the last three months,

- Fixed broadband Internet subscriptions per 100 population (C4) - Number of fixed-broadband internet subscriptions per 100 population,

- Natural digital demand (C5) - Number of online searches index ( $0-100$ best),

- Quality of electricity supply (C6) - How reliable is the electricity supply in a particular country (lack of interruptions and lack of voltage fluctuations)? - 1 to 7 score, where $1=$ extremely unreliable; $7=$ extremely reliable,

- Mobile network coverage in the percentage of the population (C7) - Percentage of the total population covered by a mobile network signal,

- Mobile-cellular telephone subscriptions per 100 population (C8) - Number of mobile-cellular telephone subscriptions per 100 population.

Table 1. Descriptive statistics of travel and tourism ICT readiness indicators of selected European countries

\begin{tabular}{|l|l|l|l|l|l|}
\cline { 2 - 6 } \multicolumn{1}{c|}{} & \multicolumn{1}{c|}{ N } & \multicolumn{1}{c|}{ Minimum } & \multicolumn{1}{c|}{ Maximum } & \multicolumn{1}{c|}{ Mean } & \multicolumn{1}{c|}{ Std. Deviation } \\
\hline C1 & 38 & 4.01 & 6.10 & 5.1539 & .62972 \\
\hline C2 & 38 & 3.83 & 6.25 & 5.1921 & .66725 \\
\hline C3 & 38 & .57 & .98 & .7955 & .10983 \\
\hline C4 & 38 & 90.42 & 170.85 & 123.2947 & 18.50838 \\
\hline C5 & 38 & 41.66 & 154.12 & 87.7950 & 25.69770 \\
\hline C6 & 38 & 4.57 & 6.77 & 5.8524 & .75387 \\
\hline C7 & 38 & .27 & 91.95 & 26.7445 & 25.49666 \\
\hline C8 & 38 & .91 & 1.00 & .9954 & .01474 \\
\hline
\end{tabular}

Source: Author's calculation

The information-technology readiness of the tourism sector of the selected European countries will be analysed in the context of finding the alternative (country) that has the best-balanced values of the mentioned indicators. The optimal alternative will be assessed by ranking the countries using the Technique for Order of Preference by Similarity to Ideal Solution (TOPSIS) method for multi-criteria decision-making. In order to apply the selected multi-criteria decision-making method, the criteria weights need to be determined. There are several methods for determining the weight coefficients of the criteria, and in this paper two methods, Principal Component Analysis (PCA) and Step-wise Weight Assessment Ratio Analysis (SWARA), will be applied, in order to determine the influence of the application of different methods for determining the weights of the criteria on the final order of alternatives. In the second step, the ranking of selected European countries according to their ICT readiness will be performed using the TOPSIS method. Accordingly, the main hypothesis of this research is that different techniques for determining the criteria weights lead to a different ranking of alternatives when applied in the same method of multi-criteria decision making.

\section{ANALYSIS OF THE OBTAINED RESULTS}

The first part of the analysis is focused on determining the weight coefficients of the criteria using factor analysis. The basis of each factor analysis is the correlation matrix of the original variables. Namely, for the factor analysis to make sense, the original variables, of which there are 8 in the 
given research, must be mutually correlated. Table 2 shows the correlation matrix for 8 perceived ICT indicators. As can be seen on the main diagonal there is number 1, and as the matrix is symmetrical, only one part of the table outside the diagonal is observed. In the given statistical model, the correlation coefficients will be observed in the lower left part of the upper triangle, while the results of the null hypothesis test are observed in the lower part of the table. Namely, the validity of the null hypothesis that the individual correlation coefficients are equal to zero is examined. According to the results of this test, for values of the realized level of the significance test greater than 0.05 , we accept the null hypothesis that these correlation coefficients are equal to zero (Soldić-Aleksić \& Chroneos-Krasavac, 2009). Thus, for example, we see that the correlation coefficients of variable $\mathrm{C} 1$ and variables $\mathrm{C} 4, \mathrm{C} 7$ and $\mathrm{C} 8$ can be accepted by the null hypothesis.

Table 2. Correlation coefficients between variables

\begin{tabular}{|c|c|c|c|c|c|c|c|c|c|}
\hline & & C1 & $\mathrm{C2}$ & $\mathrm{C3}$ & C4 & C5 & C6 & C7 & C8 \\
\hline \multirow{8}{*}{ ن } & $\mathrm{C} 1$ & 1.000 & .828 & .819 & .240 & .560 & .823 & .140 & .096 \\
\hline & $\mathrm{C} 2$ & .828 & 1.000 & .648 & .242 & .510 & .681 & .054 & -.104 \\
\hline & C3 & .819 & .648 & 1.000 & .105 & .527 & .760 & -.039 & .009 \\
\hline & $\mathrm{C} 4$ & $.240 *$ & .242 & .105 & 1.000 & .261 & .106 & .038 & -.345 \\
\hline & $\mathrm{C} 5$ & .560 & .510 & .527 & .261 & 1.000 & .492 & .013 & .055 \\
\hline & C6 & .823 & .681 & .760 & .106 & .492 & 1.000 & .283 & .065 \\
\hline & $\mathrm{C} 7$ & .140 & .054 & -.039 & .038 & .013 & .283 & 1.000 & $.063 *$ \\
\hline & $\mathrm{C} 8$ & .096 & -.104 & .009 & -.345 & .055 & .065 & .063 & 1.000 \\
\hline \multirow{8}{*}{  } & $\mathrm{C} 1$ & & .000 & .000 & .073 & .000 & .000 & .201 & .283 \\
\hline & $\mathrm{C} 2$ & .000 & & .000 & .072 & .001 & .000 & .373 & .268 \\
\hline & $\mathrm{C} 3$ & .000 & .000 & & .265 & .000 & .000 & .407 & .479 \\
\hline & C4 & .073 & .072 & .265 & & .057 & .264 & .410 & .017 \\
\hline & $\mathrm{C} 5$ & .000 & .001 & .000 & .057 & & .001 & .470 & .372 \\
\hline & C6 & .000 & .000 & .000 & .264 & .001 & & .043 & .350 \\
\hline & C7 & .201 & .373 & .407 & .410 & .470 & .043 & & .353 \\
\hline & $\mathrm{C} 8$ & .283 & .268 & .479 & .017 & .372 & .350 & .353 & \\
\hline
\end{tabular}

* Level of significance is 0.05 .

Source: Author's calculation

Formal tests to justify factor analysis are Bartlett's test and KMO statistics (Kaiser-Meyer-Olkin sample adequacy measure). The first test is used to test the null hypothesis that there is no significant correlation between the original variables and is based on Chi-square statistics. If these statistics are higher, it is more likely that the null hypothesis will be rejected. The results in Table 3 indicate that the null hypothesis can be rejected $($ Sig. $=0.000$ ). Regarding KMO statistics (which compares the values of the observed correlation coefficients with partial coefficients), the application of factor analysis is recommended if its value is higher than 0.5 (Soldić-Aleksić \& Chroneos-Krasavac, 2009). The value of KMO statistics is 0.700 , which justifies the application of the factor analysis.

Table 3. KMO and Bartlett's Test

\begin{tabular}{|l|l|l|}
\hline \multicolumn{2}{|c|}{ Kaiser-Meyer-Olkin Measure of Sampling Adequacy. } & .700 \\
\hline \multirow{3}{*}{ Bartlett's Test of Sphericity } & Approx. Chi-Square & 157.484 \\
\cline { 2 - 3 } & df & 28 \\
\cline { 2 - 3 } & Sig. & .000 \\
\hline
\end{tabular}

Source: Author's calculation

When conducting factor analysis on the mentioned variables, it is necessary to indicate the method of factor analysis. In the observed model, the principal components procedure was chosen as 
the method of factor extraction. For the criteria of factor selection, eigenvalues associated with factors greater than 1 were taken. Table 4 shows that the first 3 factors have a value greater than 1 , and the percentage of explained variance is $77.88 \%$, which supports the validity of the model.

Table 4. Total Variance Explained

\begin{tabular}{|c|c|c|c|c|c|c|c|c|c|}
\hline \multirow{2}{*}{$\begin{array}{c}\text { Compo- } \\
\text { nent }\end{array}$} & \multicolumn{3}{|c|}{ Initial Eigenvalues } & \multicolumn{3}{c|}{$\begin{array}{c}\text { Extraction Sums of Squared } \\
\text { Loadings }\end{array}$} & \multicolumn{3}{c|}{ Rotation Sums of Squared } \\
Loadings
\end{tabular}

* Extraction Method: Principal Component Analysis.

Source: Author's calculation

After defining the most important factors, the next step in the factor analysis refers to the rotation of factors with certain factor weights. In the specific model, factor weights greater than 0.3 were chosen. For these reasons, the orthogonal factor rotation procedure (Varimax) was applied. After multiple factor rotation, a factor matrix was obtained, where high values of factor weights can be distinguished for each factor (Table 5).

Table 5. Rotated component matrix

\begin{tabular}{|l|l|l|l|}
\cline { 2 - 4 } \multicolumn{1}{c|}{} & \multicolumn{3}{c|}{ Component } \\
\cline { 2 - 4 } \multicolumn{1}{c|}{1} & & \multicolumn{1}{c|}{3} \\
\hline C1 & .946 & & \\
\hline C3 & .891 & & \\
\hline C6 & .866 & & \\
\hline C2 & .848 & -.828 & \\
\hline C5 & .706 & .801 & \\
\hline C8 & & & .987 \\
\hline C4 & & & \\
\hline C7 & & & \\
\hline
\end{tabular}

Extraction Method: Principal Component Analysis.

Rotation Method: Varimax with Kaiser Normalization

a. Rotation converged in 4 iterations.

Source: Author's calculation

Thus, the variables $\mathrm{C} 1, \mathrm{C} 2, \mathrm{C} 3, \mathrm{C} 5$ and $\mathrm{C} 6$ have high weight coefficients with the first factor. The squares of the weight coefficients of the variables for the given factors represent the proportions of the variance of certain variables that are attributed to the action of the given factors (Soldić-Aleksić \& Chroneos-Krasavac, 2009). Consequently, in a stated model for the first factor the following relations can be derived:

- $0.946^{2}=0,89=89 \%$

- $0.891^{2}=0,79=79 \%$

- $0.866^{2}=0,75=75 \%$ 
- $0.848^{2}=0,72=72 \%$.

- $0.706^{2}=0.50=50 \%$

Therefore, it is concluded that the first factor explains $89 \%$ of the variance of variable $\mathrm{C} 1,79 \%$ of variable $\mathrm{C} 3,75 \%$ of variable $\mathrm{C} 6,72 \%$ of variable $\mathrm{C} 2$ and $50 \%$ of variable $\mathrm{C} 5$. The factor weight plot of three factors is shown in Figure 1.
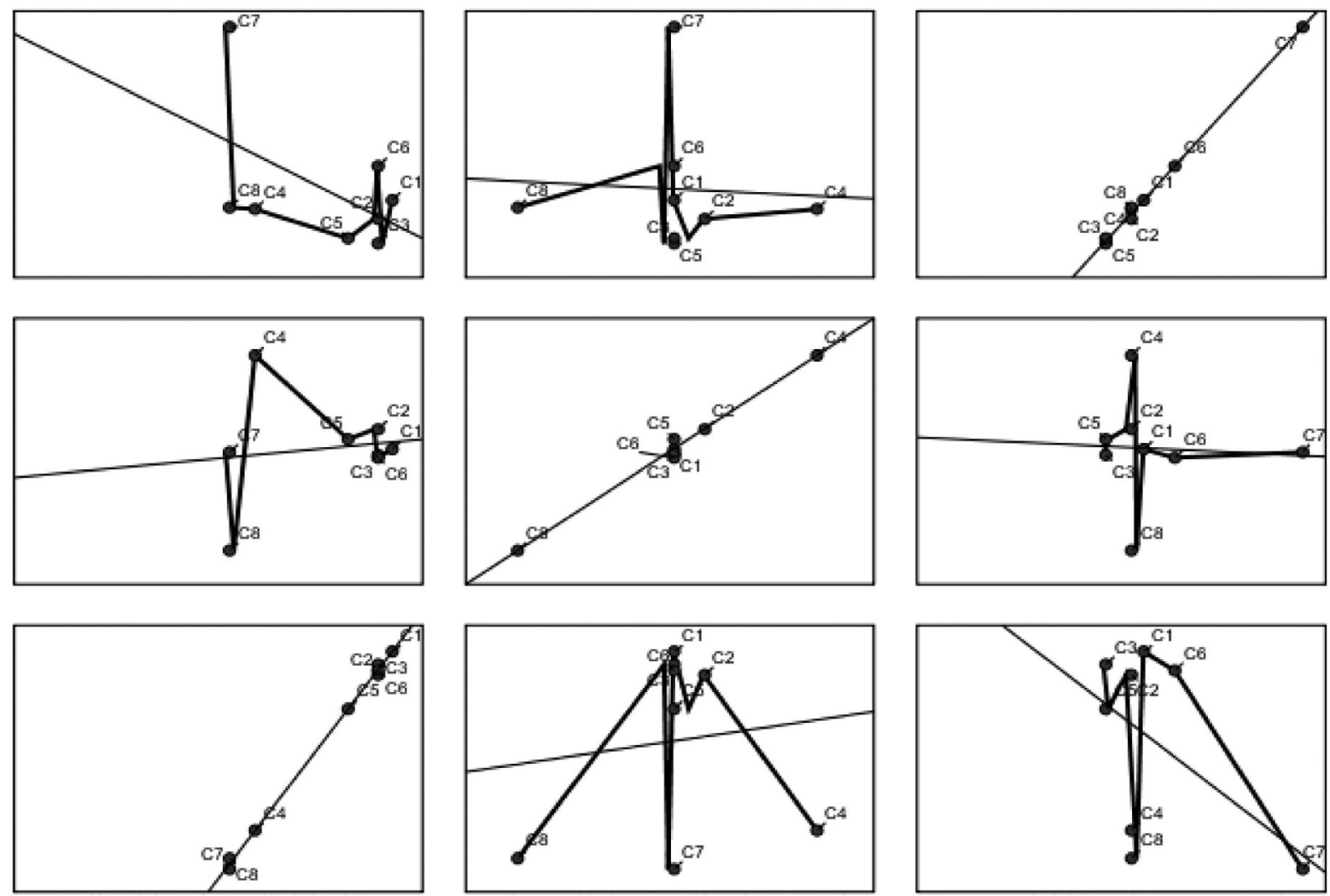

Figure 1. Component matrix plot

Source: Author's calculation

The results in the factor scores matrix confirm the high values of individual coefficients related to the variables that make up the factors (Table 6).

Table 6. Component score coefficient matrix

\begin{tabular}{|l|l|l|l|}
\cline { 2 - 4 } \multicolumn{1}{c|}{} & \multicolumn{2}{c|}{ Component } \\
\cline { 2 - 4 } \multicolumn{1}{c|}{} & \multicolumn{1}{c|}{ 2 } & \multicolumn{1}{c|}{3} \\
\hline $\mathbf{C 1}$ & .255 & -.034 & .036 \\
\hline $\mathbf{C 2}$ & .226 & .090 & -.037 \\
\hline $\mathbf{C 3}$ & .259 & -.075 & -.164 \\
\hline $\mathbf{C 4}$ & .006 & .583 & .082 \\
\hline $\mathbf{C 6}$ & .198 & .034 & -.120 \\
\hline $\mathbf{C 7}$ & .222 & -.078 & .199 \\
\hline $\mathbf{C 8}$ & -.068 & .027 & .917 \\
\hline
\end{tabular}

Extraction Method: Principal Component Analysis. Rotation Method:

Varimax with Kaiser Normalization. Component Scores.

Source: Author's calculation 
Based on the given coefficients that are multiplied by the values of the variables, the values of the factors are shown in the form of the following relations:

$$
\begin{aligned}
& F_{1}=0.255 * C 1+0.226 * C 2+0.259 * C 3+0.198 * C 5+0.222 * C 6 \\
& F_{2}=0.583 * C 4-0.612 * C 8 \\
& F_{3}=0.917 * C 7
\end{aligned}
$$

Weight assessment approaches have an important role in solving multi-criteria decision-making problems. So, the next step of the analysis in this paper is dedicated to the construction of the weights from the matrix of factor loadings after rotation, given that the square of factor loadings represents the proportion of the total unit variance of the indicator which is explained by the factor. The estimates of rotated loadings will be used for weights calculation. Weights are normalized squared factor loading, e.g. $0.244=\left(0.946^{\wedge} 2\right) / 2.64$ which is the portion of the variance of the first factor explained by the variable $\mathrm{C} 1$ (Nardo et al.,2005). The variance of calculated variables' weights within components and individual weights of Components, in this last step of PCA, will

\begin{tabular}{|c|c|c|c|c|c|c|}
\hline \multirow[b]{2}{*}{ Variables } & \multicolumn{2}{|c|}{ Component 1} & \multicolumn{2}{|c|}{ Component 2} & \multicolumn{2}{|c|}{ Component 3} \\
\hline & Loadings & $\begin{array}{c}\text { Weights of } \\
\text { variables } \\
\text { within } \\
\text { Component } 1\end{array}$ & Loadings & $\begin{array}{c}\text { Weights of } \\
\text { variables } \\
\text { within } \\
\text { Component } 2\end{array}$ & Loadings & $\begin{array}{l}\text { Weights of } \\
\text { variables } \\
\text { within } \\
\text { Component } 3\end{array}$ \\
\hline C1 & 0.946 & 0.244 & & & & \\
\hline $\mathrm{C2}$ & 0.848 & 0.196 & & & & \\
\hline C3 & 0.891 & 0.217 & & & & \\
\hline C4 & & & 0.801 & 0.486 & & \\
\hline C5 & 0.706 & 0.136 & & & & \\
\hline C6 & 0.866 & 0.205 & & & & \\
\hline C7 & & & & & 0.987 & 1.000 \\
\hline C8 & & & -0.828 & 0.519 & & \\
\hline Expl.VAR & & 3.656 & 1.32 & & 0.974 & \\
\hline
\end{tabular}
be used for the calculation of weights of variables according to the results from Table 7.

Table 7. Factor loading and weights of selected indicators

Source: Author's calculation

Another method that will be applied to determine the weight coefficients of the criteria is the SWARA method. The main feature of SWARA method is the possibility to use experts' estimations about significance ratio of the attributes in the process of weights determination. SWARA method represents one of the newest methods for criteria weights determination. The main advantage compared to others methods of weights determination is the straightforwardness of weights calculation where each expert has to choose the importance of each criterion (Zolfani \& Saparauskas, 2013). Next, each expert ranks all the criteria from the first to the last one. The ability to estimate experts' opinions about the importance ratio of the criteria in the process of their weight's determination is the main element of this method (Zolfani \& Saparauskas, 2013). The computational procedure of the SWARA method has few specific steps in determining the relative weights of criteria (Stanujkić et al., 2015):

Step 1. The criteria are sorted in descending order based on their expected significances. 
Step 2. Starting from the second criterion, the respondent expresses the relative importance of criterion $j$ in relation to the previous $(j-1)$ criterion, for each particular criterion. According to (Kersuliene et al. 2010), this ratio is called the Comparative importance of average value $\left(s_{j}\right)$.

Step 3. Determine the coefficient $k_{j}$ using the following relation:

$$
k_{j}=\left\{\begin{array}{cc}
1 & j=1 \\
s_{j}+1 & j>1
\end{array}\right.
$$

Step 4. Determine the recalculated weight $q_{j}$ as follows:

$$
q_{j}=\left\{\begin{array}{cc}
1 & j=1 \\
\frac{k_{j}-1}{k_{j}} & j=1
\end{array}\right.
$$

Step 5. The relative weights of the evaluation criteria are determined as follows:

$$
w_{j}=\frac{q_{j}}{\sum_{k=1}^{n} q_{k}}
$$

where $w_{j}$ denotes the relative weight of criterion $j$.

In the second step of the analysis the TOPSIS method as a multi-criteria decision-making method will be used for the evaluation of alternatives. TOPSIS method performs prioritization of alternatives based on their geometric distance from the positive-ideal and negative-ideal solution. Accordingly, it can be concluded that the best alternative will be the one with the shortest distance to the positive-ideal solution, and with the greatest distance from the negative-ideal solution (Rađenović \& Veselinović, 2017). TOPSIS method involves the use of specific steps (Yoon \& Hwang, 1995):

Step 1: Determination of normalized decision matrix R with coefficients $r_{i j}$ obtained by vector normalization:

$$
r_{i j}=\frac{x_{i j}}{\sqrt{\sum_{i=1}^{m} x_{i j}^{2}}} i=1,2, \ldots, \mathrm{m}, j=1,2, \ldots, \mathrm{n} .
$$

Step 2: Determination of weight normalized decision matrix $\mathrm{V}$ with coefficients $v_{i j}$ which are calculated by multiplying each element of each column of the normalized decision matrix by the adequate weights:

$$
v_{i j}=r_{i j} w_{j}
$$

In this paper weights were obtained using PCA and SWARA techniques to quantify the relative importance of the selected ICT readiness criteria.

Table 8. Weighted coefficients of PCA and SWARA method

\begin{tabular}{|c|l|l|l|l|l|l|l|l|}
\hline \multirow{2}{*}{ Method } & \multicolumn{7}{|c|}{ Weighted coefficients } \\
\cline { 2 - 9 } & \multicolumn{1}{|c|}{ C1 } & \multicolumn{1}{|c|}{ C2 } & C3 & C4 & C5 & C6 & C7 & C8 \\
\hline PCA & 0,035 & 0,222 & 0,027 & 0,138 & 0,011 & 0,025 & 0,568 & 0,157 \\
\hline SWARA & 0,184 & 0,153 & 0,138 & 0,123 & 0,085 & 0,113 & 0,074 & 0,131 \\
\hline
\end{tabular}

Source: Author's calculation 
Step 3: Determination of positive ideal and negative ideal solution. The values which describe positive ideal solution and negative ideal solution are defined as:

$$
\begin{aligned}
& A^{*}=\left\{v_{1}^{*}, v_{2}^{*}, \ldots, v_{j}^{*}, \ldots, v_{n}^{*}\right\}=\left\{\left(\max _{i} v_{i j} \mid j \in J_{1}\right) \wedge\left(\min _{i} v_{i j} \mid j \in J_{2}\right), i=1,2, \ldots, m\right\} \\
& A^{-}=\left\{v_{1}^{-}, v_{2}^{-}, \ldots, v_{j}^{-}, \ldots, v_{n}^{-}\right\}=\left\{\left(\min _{i} v_{i j} \mid j \in J_{1}\right) \wedge\left(\max _{i} v_{i j} \mid j \in J_{2}\right), i=1,2, \ldots, m\right\}
\end{aligned}
$$

Where $J_{1}$ represents the set of revenue criteria and $J_{2}$ the set of expenditure criteria.

Step 4: Calculation of the distance (Euclidean distance) of each alternative from the positive ideal and negative ideal solution. The distance from the positive ideal solution is calculated as:

$$
S_{i}^{*}=\sqrt{\sum_{j=1}^{n}\left(v_{i j}-v_{j}^{*}\right)^{2}}, \quad i=1,2, \ldots, m
$$

Similarly, the distance of alternative from the negative ideal solution is calculated as:

$$
S_{i}^{-}=\sqrt{\sum_{j=1}^{n}\left(v_{i j}-v_{j}^{-}\right)^{2}}, \quad i=1,2, \ldots, m
$$

Step 5: Calculation of the proximity index $\left(C_{i}^{*}\right)$, which represents relative proximity of alternative to the positive ideal solution. The index is calculated as:

$$
C_{i}^{*}=\frac{S_{i}^{-}}{S_{i}^{*}+S_{i}^{-}}, i=1,2 \ldots ., m
$$

Proximity index takes values in range $0 \leq C_{i}^{*} \leq 1$. If $C_{i}^{*}=0$ the alternative represents a negative ideal solution, and if $C_{i}^{*}=1$ the observed alternative corresponds with the positive ideal solution.

Step 6: Ranking of the alternatives according to their proximity index. The optimum alternative is the one with the highest proximity index.

\section{COMPARATIVE ANALYSIS OF THE RESULTS}

The results of the conducted multi-criteria analysis are shown in Table 9. The results obtained using the integrated SWARA-TOPSIS approach indicate that Italy is the best-ranked country. On the other hand, the results obtained using the integrated PCA-TOPSIS approach indicate that the best-ranked country is Belgium.

Table 9. Rankings of European countries according to different techniques

\begin{tabular}{|l|c|c|c|c|}
\hline \multirow{2}{*}{ Country } & \multicolumn{2}{|c|}{ PCA-TOPSIS } & \multicolumn{2}{c|}{ SWARA-TOPSIS } \\
\cline { 2 - 5 } & Proximity index & Rank & Proximity index & Rank \\
\hline Albania & 0,35860 & 27 & 0,19129 & 32 \\
\hline Austria & 0,60256 & 7 & 0,33539 & 22 \\
\hline Belgium & 0,78671 & 1 & 0,41080 & 15 \\
\hline Bosnia and Herzegovina & 0,31936 & 30 & 0,45007 & 13 \\
\hline Bulgaria & 0,48676 & 13 & 0,28980 & 26 \\
\hline Croatia & 0,47111 & 16 & 0,61522 & 3 \\
\hline
\end{tabular}




\begin{tabular}{|c|c|c|c|c|}
\hline Cyprus & 0,66131 & 5 & 0,45300 & 11 \\
\hline Czech Republic & 0,54369 & 9 & 0,45630 & 9 \\
\hline Denmark & 0,30559 & 32 & 0,32517 & 23 \\
\hline Estonia & 0,76741 & 4 & 0,34774 & 20 \\
\hline Finland & 0,78670 & 2 & 0,41080 & 16 \\
\hline France & 0,41104 & 24 & 0,59242 & 6 \\
\hline Germany & 0,43707 & 23 & 0,34344 & 21 \\
\hline Greece & 0,31936 & 31 & 0,45007 & 14 \\
\hline Hungary & 0,29385 & 35 & 0,15383 & 34 \\
\hline Ireland & 0,47600 & 15 & 0,38780 & 17 \\
\hline Italy & 0,51622 & 11 & 0,71535 & 1 \\
\hline Luxembourg & 0,48676 & 14 & 0,28980 & 27 \\
\hline Malta & 0,48867 & 12 & 0,52208 & 8 \\
\hline Moldova & 0,25460 & 37 & 0,11454 & 36 \\
\hline Montenegro & 0,46252 & 20 & 0,21676 & 30 \\
\hline Netherlands & 0,46904 & 18 & 0,35649 & 19 \\
\hline North Macedonia & 0,25853 & 36 & 0,10819 & 37 \\
\hline Norway & 0,54964 & 8 & 0,54120 & 7 \\
\hline Poland & 0,78186 & 3 & 0,38721 & 18 \\
\hline Portugal & 0,34829 & 28 & 0,65987 & 2 \\
\hline Romania & 0,39946 & 25 & 0,19561 & 31 \\
\hline Russian Federation & 0,46633 & 19 & 0,29041 & 25 \\
\hline Serbia & 0,39433 & 26 & 0,16466 & 33 \\
\hline Slovak Republic & 0,44749 & 22 & 0,24621 & 29 \\
\hline Slovenia & 0,34746 & 29 & 0,25237 & 28 \\
\hline Spain & 0,47111 & 17 & 0,61522 & 4 \\
\hline Sweden & 0,66131 & 6 & 0,45300 & 12 \\
\hline Switzerland & 0,54369 & 10 & 0,45630 & 10 \\
\hline Turkey & 0,30559 & 33 & 0,32517 & 24 \\
\hline Ukraine & 0,30100 & 34 & 0,13134 & 35 \\
\hline United Kingdom & 0,45741 & 21 & 0,61043 & 5 \\
\hline
\end{tabular}

Source: Author's calculation

The differences that exist in the ranking of the selected European countries using the TOPSIS method are primarily due to the different approaches in determining the weighting coefficients. The application of PCA is a kind of sublimation of ICT readiness tourism indicators by factors based on the value of loadings, where later, using variance, weights are calculated for each variable separately, first within the Component that they make and later for each individually. On the other hand, the SWARA method, as a still new concept of weight determination, is based on the simplicity of the model and individual expert assessment of the criteria importance. In this method, experts and researchers have a significant role in the evaluation and calculation of the value of the criteria, where they primarily use their implicit knowledge, information and experiences.

In order to check the relationship between the obtained ranking results, using both approaches, a correlation analysis was performed by Spearman's rank order correlation. Spearman's rank-order correlation is used to examine the strength of the relationship and the direction of the association between the obtained rank values for both methods (Marjanović et al., 2019). The analysis is performed in the SPSS statistical software and indicates that there is a moderate positive statistically significant relationship between the two variables (PCA_TOPSIS and SWARA_TOPSIS) with the Spearman's rho value of 0.494 (Table 10). This indicates that there is a moderate rank inversion when different methods for determining weights are applied. 
Table 10. Spearman's rank-order correlation for PCA_TOPSIS and SWARA_TOPSIS ranking values

\begin{tabular}{|c|c|c|c|c|}
\hline \multicolumn{3}{|c|}{ Correlations } & PCA_TOPSIS & SWARA_TOPSIS \\
\hline \multirow{6}{*}{ Spearman's rho } & \multirow{3}{*}{ PCA_TOPSIS } & $\begin{array}{l}\text { Correlation } \\
\text { Coefficient }\end{array}$ & 1.000 & $.494^{* *}$ \\
\hline & & Sig. (2-tailed) & . & .000 \\
\hline & & $\mathrm{N}$ & 37 & 37 \\
\hline & \multirow{3}{*}{$\begin{array}{l}\text { SWARA } \\
\text { TOPSIS }\end{array}$} & $\begin{array}{l}\text { Correlation } \\
\text { Coefficient }\end{array}$ & $.494^{* *}$ & 1.000 \\
\hline & & Sig. (2-tailed) & .000 & . \\
\hline & & $\mathrm{N}$ & 37 & 37 \\
\hline
\end{tabular}

** $\quad$ Correlation is significant at the 0.01 level (2-tailed).

Source: Author's calculation

Hence, the research hypothesis is confirmed, the application of different techniques for determining the criteria weights leads to a different ranking of alternatives when applied in the same method of multi-criteria decision-making.

\section{FUTURE RESEARCH DIRECTIONS}

Further research in this area can be directed towards identifying the trend of ICT readiness in the tourism sector of European countries by extending the period of analysis. Also, it is possible to identify the basic determinants of ICT readiness in the tourism sector by applying panela data regression analysis.

\section{CONCLUSION}

The competitiveness of tourist organizations and destinations is increasingly conditioned by the application of ICTs. In modern conditions, ICTs are becoming a powerful tool that can be used to achieve advantages in promoting and strengthening the strategy and business of the tourism industry (Bethapudi, 2013). The success of the implementation of ICTs in the tourism sector is a prerequisite for the development of contemporary tourism. The application of ICT provides many benefits to the tourism sector, primarily reflected in facilitating business and improving efficiency and productivity.

Therefore, the main goal of this paper was to offer a possible approach to assess the ICT readiness of the tourism sector in European countries using the technique of multi-criteria decision-making. In addition, the sub-goal was to present a comparative analysis of the results obtained by applying different methods for determining weight coefficients. The assessment of ICT readiness of European countries was conducted using a two-step analysis. In the first step, weight coefficients were determined by applying factor analysis and SWARA method to the selected set of criteria. In the second step, using the TOPSIS method, the ranking results were obtained, after which a comparative analysis of the results was performed to determine whether the application of different methods for determining the weight coefficients of the criteria led to the inversion of the rank. The results indicate that the application of different methods for determining weight coefficients on the same data set leads to moderate rank inversion.

The conducted research faces certain limitations. The obtained results are largely determined by the selected indicators, where the application of some other indicators can lead to different results. In addition, it is possible that the results of the analysis are influenced by the selected multicriteria method, and the application of another multicriteria method may lead to different results. 


\section{ACKNOWLEDGMENT}

The research study has been supported by the Republic of Serbia's Ministry of Education, Science and Technology: No.451-03-68/2020-14/200371.

\section{REFERENCES}

Aramendia Muneta, M. E., \& Ollo López, A. (2013). ICT Impact on tourism industry. International Journal of Management Cases, 15 (2): 87-98.

Assaf, A. G., \& Tsionas, M. (2018). The estimation and decomposition of tourism productivity. Tourism Management, 65, 131-142.

Berne, C., Garcia-Gonzalez, M., \& Mugica, J. (2012). How ICT shifts the power balance of tourism distribution channels. Tourism Management, 33(1), 205-214.

Berné, C., García-González, M., García-Uceda, M. E., \& Múgica, J. M. (2015). The effect of ICT on relationship enhancement and performance in tourism channels. Tourism Management, 48, 188-198.

Bethapudi, A. (2013). The role of ICT in tourism industry. Journal of applied economics and business, 1(4), 67-79.

Bradić-Martinović, A., \& Miletić, B. (2017, June). ICT readiness as a factor of competitiveness of Serbian tourism. In TISC-Tourism International Scientific Conference Vrnjačka Banja (pp. 448-469).

Bramwell, B., \& Lane, B. (1999). Sustainable tourism: Contributing to the debates. Journal of Sustainable Tourism, 7(1), 1-5.

Brandt, T., Bendler, J., \& Neumann, D. (2017). Social media analytics and value creation in urban smart tourism ecosystems. Information \& Management, 54(6), 703-713.

Damnjanović, A. (2016). The Impact of ICT in Business in Tourism-Improving Efficiency, Productivity and Business Performance. In Sinteza 2016-International Scientific Conference on ICT and E-Business Related Research (pp. 550-558). Singidunum University.

Duffy, S. (2010, June). Factors influencing technology adoption amongst tourism SMEs. In Tourism and Hospitality Research in Ireland Conference, Ireland. Shannon College of Hotel Management.

Januszewska, M., Jaremen, D., \& Nawrocka, E. (2015). The effects of the use of ICT by tourism enterprises. Zeszyty Naukowe Uniwersytetu Szczecińskiego. Service Management, 16, 65-73.

Karanasios, S., \& Burgess, S. (2008). Tourism and Internet adoption: a developing world perspective. International Journal of Tourism Research, 10(2), 169-182.

Keršuliene, V., Zavadskas, E.K., \& Turskis, Z. (2010). Selection of rational dispute resolution method by applying new step-wise weight assessment ratio analysis (SWARA), Journal of Business Economics and Management, 11(2), 243-258, DOI: 10.3846 / jbem. 2010.12

Kladou, S., \& Mavragani, E. (2015). Assessing destination image: An online marketing approach and the case of TripAdvisor. Journal of Destination Marketing \& Management, 4(3), 187-193.

Kontogianni, A., \& Alepis, E. (2020). Smart tourism: State of the art and literature review for the last six years. Array, 6, 100020.

Kumar, N., \& Kumar, R. R. (2020). Relationship between ICT and international tourism demand: A study of major tourist destinations. Tourism Economics, 26(6), 908-925.

Law, R., Buhalis, D., \& Cobanoglu, C. (2014). Progress on information and communication technologies in hospitality and tourism. International Journal of Contemporary Hospitality Management. 
Law, R., Fuchs, M., \& Ricci, F. (Eds.). (2011). Information and Communication Technologies in Tourism 2011. Vienna: Springer. doi:10.1007/978-3-7091-0503-0

Mandić, A., \& Praničević, D. G. (2019). The impact of ICT on actors involved in smart tourism destination supply chain. e-Review of Tourism Research, 16(2/3).

Marjanović, I., Rađenović, Ž., \& Marković, M. (2019). EU members multi-criteria ranking according to selected travel industry indicators, 4th International Thematic Monograph Modern Management Tools and Economy of Tourism Sector in Present Era, Association of Economists and Managers of the Balkans in cooperation with the Faculty of Tourism and Hospitality, Ohrid, North Macedonia, 639-655 ISSN 2683-5673, DOI: https://doi.org/10.31410/tmt.2019

Mihajlović, I. (2012). The impact of information and communication technology (ICT) as a key factor of tourism development on the role of Croatian travel agencies. International Journal of Business and Social Science, 3(24), 151-159.

Narangajavana, Y., Fiol, L. J. C., Tena, M. Á. M., Artola, R. M. R., \& García, J. S. (2017). The influence of social media in creating expectations. An empirical study for a tourist destination. Annals of Tourism Research, 65, 60-70.

Nardo, M., Saisana, M., Saltelli, A. \& Tarantola, S. (2005). Tools for Composite Indicators Building, Institute for the Protection and Security of the Citizen Econometrics and Statistical Support to Antifraud Unit I-21020 Ispra (VA) Italy. https://publications.jrc.ec.europa.eu/repository/bitstream/JRC31473/EUR\%2021682\%20EN.pdf

Navío-Marco, J., Ruiz-Gómez, L. M., \& Sevilla-Sevilla, C. (2018). Progress in information technology and tourism management: 30 years on and 20 years after the internet-Revisiting Buhalis \& Law's landmark study about eTourism. Tourism management, 69, 460-470.

Neuhofer, B., Buhalis, D., \& Ladkin, A. (2014). A typology of technology-enhanced tourism experiences. International journal of tourism research, 16(4), 340-350.

OECD (2020). OECD Tourism Trends and Policies 2020, https://www.oecd-ilibrary.org/ sites/6b47b985-en/index.html?itemId=/content/publication/6b47b985-en

Patwary, A. K., Chowdury, M. M., Mohamed, A. E., \& Azim, M. S. (2020). Dissemination of Information and Communication Technology (ICT) in tourism industry: Pros and cons. International Journal of Multidisciplinary Sciences and Advanced Technology, 1(8), 36-42.

Petrovic, J., \& Milićević, S. (2020). The ICT Impact on Inbound and Outbound Tourism Demand in the EU. Management: Journal of Sustainable Business and Management Solutions in Emerging Economies, 25(1), 47-55.

Rađenović, Ž., \& Veselinović, I. (2017). Integrated AHP-TOPSIS method for the assessment of health management information systems efficiency, Economic themes, 55(1), 121-142. DOI 10.1515/ethemes-2017-0008

Reinders, J., \& Baker, M. (1998). The future for direct retailing of travel and tourism products: the influence of information technology. Progress in Tourism and Hospitality Research, 4(1), 1-15.

Soldić-Aleksić, J. \& Krasavac-Chroneos, B. (2009). Quantitative techniques in market research - Application of SPSS computer package (in Serbian), Publishing Center of the Faculty of Economics in Belgrade, ISBN: 978-86-403-0967-7

Stanujkic, D., Karabasevic, D. \& Zavadskas, E.K. (2015). A Framework for the Selection of a Packaging Design Based on the SWARA Method, Inzinerine Ekonomika-Engineering Economics, 26(2), 181-187, http://dx.doi.org/10.5755/j01.ee.26.2.8820

Štetić, S., Šimičević, D., \& Milićević, S. (2017). Information and communication technology as a driving force of changes in tourism. Quaestus, (10), 142.

Ukpabi, D. C., \& Karjaluoto, H. (2017). Consumers' acceptance of information and communications technology in tourism: A review. Telematics and Informatics, 34(5), 618-644. 
Wang, Y., \& Fesenmaier, D. R. (2007). Collaborative destination marketing: A case study of Elkhart county, Indiana. Tourism management, 28(3), 863-875.

WEF (2019). Travel and Tourism ICT readiness, https://tcdata360.worldbank.org/indicators/tour. ict?country $=$ BRA\&indicator $=3546 \& v i z=$ line_chart\&years $=2015,2017$

Werthner, H., \& Klein, S. (1999). ICT and the changing landscape of global tourism distribution. Electronic markets, 9(4), 256-262.gtt

WTTC (2019). Economic Impact Reports, https://wttc.org/Research/Economic-Impact

Yoon, K., \& Hwang, C. (1995). Multiple attribute decision-making: an introduction. Sage Publisher

Zeng, B., \& Gerritsen, R. (2014). What do we know about social media in tourism? A review. Tourism management perspectives, 10, 27-36.

Zolfani, S.H., \& Saparauskas, J. (2013). New Application of SWARA Method in Prioritizing Sustainability Assessment Indicators of Energy System, Inzinerine Ekonomika-Engineering Economics, 24(5), 408-414, http://dx.doi.org/10.5755/j01.ee.26.2.8820 
